\title{
Are there Village Regulations that Regulate Home Stay Using Village Yard Land in Ubud Village, Gianyar-Bali?
}

\author{
A. A. N. Harmini*, Nyoman Mastiani Nadra, A.A. \\ Gede Oka Parwata \\ Tourism Department \\ Politeknik Negeri Bali \\ Badung, Indonesia \\ *gunghar@pnb.ac.id
}

\author{
I Dewe Gede Ari Pemayun \\ Faculty of Law \\ Udayana University \\ Badung, Indonesia
}

\begin{abstract}
Protection against customary land is considered important because land is a natural resource that cannot be renewed. This study aims to find out whether there is a village regulation that regulates the village yard land that is converted into tourism facilities in the form of home stays in the tourist village of Ubud. The dynamics of globalization have a big influence on customary land, which may not switch functions and can even switch ownership from communal to individual and various other issues that have the potential to eliminate the identity of the customary land itself. Based on the research that was conducted, it turned out that the village regulation had not yet arranged a Home stay that used Village Yard Land in Ubud Village, Gianyar-Bali. This research is included in empirical research, namely legal research that analyzes and examines the legal behavior of individuals or communities who have home stays on Village yard land. Data sources used to study this empirical legal research are primary data obtained in the field, secondary data, and other approaches to enrich information. To give meaning to the data obtained by the author, he takes a historical approach. The analysis is qualitative descriptive.
\end{abstract}

Keywords—home stay, Village Yard Land, village regulation

\section{INTRODUCTION}

Bali tourism today is considered as a destiny in the history of human life. Seeing the decline of tourism due to the impact of Mount Agung's eruption some time ago, inevitably, ready to be unprepared, we Balinese community must face it as a challenge and at the same time as an opportunity to improve themselves in welcoming the future tourism. Bali chooses tourism as a priority sector to increase Regional Original Revenue, therefore, to address these conditions, Bali needs to do self-examination and improvement, especially in providing tourism facilities.

The development of tourism facilities that have been happening in Bali has been very out of control, its development is often large-scale, polluting the environment, damaging the ecosystem, utilizing productive areas, exploiting natural resources and human resources, using luxury materials, and using strategic places. The enormity of the development of tourism has caused our ancestral heritage to be disturbed; seas, mountains, temples, forests and so on are used as tourist attractions. With such excessive development, Bali needs to think about developing a more appropriate tourism facility suitable for Bali which is a small island. Of course this is a challenge, if you want to see the real situation. How in the future if Bali does not start now, it will be arranged according to existing concepts?

As an international tourist destination, Bali is demanded to be able to meet the needs of tourists both domestic tourists and foreign tourists. Even so, demands that must be met by a tourist destination, does not mean that Bali has to sacrifice itself to meet the needs of tourists, but tourists should be adjusted to enjoy the facilities that are in accordance with the facilities we have. This is often not understood by tourism actors or stakeholders in developing business in the tourism sector. Indeed, the development of tourism that is suitable for several regions in Bali is ecotourism, because this ecotourism is a contradiction of conventional tourism development as described above. The accuracy of ecotourism development for Bali can provide more benefits such as: educating the public because it implements local management, does not damage the environment, and most importantly, can prosper the community. As a domicile village, people usually compete to be able to provide various facilities needed by tourists, both accommodation restaurants, art shops, transportation, and so on.

As an initial observation in Ubud tourism area, the authors see that home stay is very suitable to be developed in the area, considering that home stays are built together with resident's house that have occupied the Land of the Village for generations so as not to damage the environment and ecosystem. Home Stay is indeed the right solution to preserve the environment, but the problems are: Home stay is built on the Village Yard Land which is owned by the Customary Village, while the villagers who build a Home Stay above the Village Yard Land do not give contribution to the Customary Village. 
Based on this background, the authors are interested in searching "Are there Village Regulations that Regulate Home Stay using Village Yard Land in Ubud Village, Gianyar-Bali?"

\section{MATERIAL AND METHODOLOGY}

\section{A. Material}

In accordance with the title of the study above there are several relevant studies that need to be described in this material which include, among others:

1) Legal actions or legal role in tourism: In Indonesia the term Law on Tourism is still not a term widely known by the public. This is very different from the facts at the international level, where various literatures that discusses issues related to tourism law and hospitality law has been widely printed. Therefore, tourism people in the country should begin to understand, implement and introduce this term in order to achieve tourism objectives based on the principles of sustainable development [1]. Law is a supporter of happiness, the law must regulate society based on two principles [1]:

- The law stipulates equal freedom for everyone to gain access to wealth, income, food, protection, authority, power, self-esteem, rights and freedom.

- The law regulates differences and equal opportunities. The difference in opportunity is intended to provide the greatest benefit to those who are most disadvantaged, while equality of opportunity is intended so that everyone has equal opportunities to achieve the prospects for welfare, income and authority. Similar views are conveyed by Sunaryati Hartono, the law functions to regulate and limit economic activities, in the hope that economic development does not neglect the rights and interests of the community [1].

Economic law has two aspects:

- Aspects of regulation of economic development efforts, in the sense of increasing overall economic life (economic development law)

- The regulatory aspect of efforts to share the results of economic development equally among all levels of society, so that every Indonesian citizen can enjoy the results of economic development in accordance with his contribution to the economic development effort. (Social economic law).

2) Village yard land (Communal land): Customary lands in Bali are in accordance with the Conversion Provisions of Law No. 5 of 1960, concerning the Basic Agrarian Law is stated in Article II as the Land of Right belong to or the Land of Right belong to the Village. Communal Land or village land consist of:

- Village land, which is the land that can be obtained or get through buying and other businesses. For example, land markets, fields, burial grounds, and so on.
- Land of Temples, namely lands (which were formerly owned by the village or controlled by the village) which are specifically used for temple purposes.

- Village Yard Land, is a land controlled by the village which is given to villagers to establish or build housing which is usually in a certain size and is almost the same for each family.

- Village Land is a land that is controlled or owned by a village whose cultivation is handed over to each villager accompanied by the right to enjoy the results. Both the Village Yard Land and the Village Land are areas of authority from the Customary Village.

The basis for this control is ulayat rights (territorial rights), namely the rights of customary law communities over the land inhabited. For the Village Yard Land and Village Land customary ties still exist, namely in the form of public obligations for villages and temples. This obligation is generally known as "ayahan" (Pay by power). So it is this suggestion that restrains or binds the lands pay by power above. So that these lands become restricted land rights. For the restricted lands, according to Bushar it will depend on the strength and weakness of the village's authority rights [2]. If customary rights are strong, the village will claim that the land belongs to the village. Likewise, if the customary rights are weak, these lands will belong to the members of the village [2].

3) Home stay: Home Stay is a type of accommodation that relies on residential homes as a place to live for tourists. The management system of this home stay has a minimal impact on the damage to the environment and the social life of the community but provides optimum benefits to the community's economy and cultural preservation.

4) Customary law: Customary law is a genuine Indonesian law whose form is not written in the form of legislation of the Republic of Indonesia which here contains elements of Religion [3].

\section{METHODOLOGY}

\section{A. Types of Research}

This research is classified as an empirical legal research, which search the existing reality relating to the use of Village Yard Land that is used as a tourism facility, especially as a home stay in the tourist area of Ubud.

\section{B. Concept and Operational Definition}

This study entitled there is a village regulation that regulates home stay above the land of the village yard in the village of Ubud. There are 2 variables that are taken into consideration in this study, namely the arrangement of home stay on the land of the Village Area and the contribution of the home stay owner to the Customary Law.

What is meant by setting up a home stay above the village yard Land is arranging the use of the Village Yard land in accordance with its function, while what is meant by the contribution of home stay owners is the compensation provided 
by the traditional villagers who utilize the Village Yard Land as a home stay to the Customary Law

\section{Area of Research and Sampling}

This research was conducted in the village of Ubud. Determination of the sample is based on the different conditions of each indigenous "banjar" (small traditional organization) in the Ubud village associated with the development of tourism which allegedly had a major influence on the conversion of the village yard land. With the development of tourism, the "banjar" sample selected purposively is: banjar Padangtegal kaja, padangtegal Mekarsari, Padangtegal Kelod whose residents have a home stay,

\section{Types and Data Sources}

The type of data in this study is divided into primary data and secondary data. Primary data is obtained from the traditional "banjar" which is used as a sample with data sources in the form of respondents consisting of "Kelihan Banjar" (leader of banjar) and villager residents who have a home stay. Secondary data is library data from books, internet, and daily or newspapers, as supporting data.

\section{E. Data Collection Techniques}

Field data collection uses interview techniques as the main technique carried out based on the interview guidelines. Library data was collected using documentation study techniques.

\section{F. Data Processing and Analysis Techniques}

Data processing is done qualitatively while the analysis is descriptive qualitative by emphasizing content analysis [4] and also complete with situational analysis that looks at the specific situation that exists in certain cases [5]. The results of data analysis are presented descriptively by describing the analysis completely with regard to the construction of home stay on the village yard land.

\section{RESULTS AND DISCUSSION}

\section{A. Ubud Profile}

Ubud is one of the domicile villages in Bali that are in great demand by foreign tourists and domestic tourists. Some of the factors that make Ubud widely chosen are the people of Ubud who are friendly, open and kind to their visitors. All of this is further enhanced by a calm atmosphere and also full of positive aura. Ubud is indeed proven successful in getting the attention of international tourists. Even Julia Roberts had come to Ubud to shoot the movie Eat, Pray, and Love.

For the spatial arrangement of Gianyar area, it is definitely divided into 4 development zones consisting of: North Zone developed by agrotourism and art craft, this development is in (three) 3 districts namely Payangan, Tampaksiring, and Tegalalang sub-districts. The East Zone was developed by sports and tourism facilities, this development was in (two) 2 sub-districts, the Gianyar sub-district and Blahbatuh. The South Zone was developed as a place to develop handicraft marketing; this development is in the Sukawati district. The West Zone was developed as a tourist and cultural arts site; this development is in the Ubud district.

\section{B. Tourism Potential in Ubud}

Ubud is one of the art places in Bali. Ubud sub-district consists of 7 villages, 13 Banjar (the smallest organization), this village can be said to be lucky areas. Tourism activities in Ubud Subdistrict grow and develop and are able to provide accumulation to various sectors, including services such as hospitality, banking and various activities of the art craft industry. Ubud is famous for its paintings, sculptures, handicrafts, gambelan (traditional music) and dance. Many paintings describe about Bali that can be found in small galleries around Ubud, and there are also museums such as Neka art Museum, Lempad Gallery, Puri Lukisan Museum, Antonio Blanco Gallery, and ARMA Museum.

For Gambelan, traditional musical instruments and Balinese dances can be found in cultural art studios. Ubud can be categorized as an international shopping place because various international branded products can be found here. Ubud is also complete with tourist information bureaus and also many tourist attractions such as monkey forest, frequent terrace and others. Which is the nature of the people in Ubud who always accept tourists friendly who come to Ubud. Ubud is known as the center of Balinese culture, this place has attracted the attention of tourists who are fascinated by Balinese culture since decades ago, where artists, composers and western scholars come to create and conduct research while enjoying the joy of living in Ubud. Other tourism potentials are cycling in rural areas and trekking.

\section{The Existence of Home stay in Ubud tourism area}

Currently the number of room occupancy in Ubud tourist area has reached 8,000 (eight thousand rooms) consisting of, home stay, budget hotels, star hotels, bungalows, pension, inn, cottages, resorts, budget hotels, guest houses, etc. [6].

Mobility of economic resources in the Ubud Tourism Area cannot be dammed with high intensity, economic activities that are the mainstay or priority of local communities in Ubud are home stay, because home stay management does not require much capital, and special skill, and can be done as a side activity (double work)

Home stays in Ubud tourism areas provide opportunities for people to act as actors in the development of sustainable tourism. The existence of home stay management carried out by the community is also one way to reduce economic leakage. The benefits of managing a home stay as a whole can be enjoyed by the local community, both directly and through a multiplayer effect. In other words, the benefits gained will be enjoyed by local residents rather than investors 
TABLE I. Mechanism OF PRESERVING Home Stay

\begin{tabular}{|l|ll|}
\hline \multicolumn{1}{|c|}{ Target } & \multicolumn{1}{c|}{ Idea and Examples } \\
\hline Natural Resources & - & Undamaged nature and environment \\
& - & Minimize energy(water, electric, etc) \\
& - & Using local materials \\
\hline Cultural & - & Local way of life \\
Resources & - & Using local style \\
& - & Keeping local genius \\
& - & Using local management \\
& - & Local control over development \\
\hline Human Resources & - & Using local labor/local worker \\
& - & Increase multiplayer effect \\
& - & Educate community \\
\hline
\end{tabular}

The understanding of the mechanism of home stay above refers to 3 environmental sustainability targets, namely: natural resources, cultural resources, and human resources. The activities of natural resource targets are not damaging to nature and the environment, minimizing energy use, and using local materials. The goal of cultural resources is to apply local ways of life, using local methods, maintaining local skill or knowledge, managing in a local way, and developing everything under local control. Human resources can be done by using local labor, increasing double impacts, and providing learning to local communities (educate community).

When home stay is developed to be accommodation or a place to stay for tourists in the Ubud Tourism Area, automatically the community protects the environment by maintaining cleanliness, learning to manage accommodation, using local staff, applying local knowledge, not requiring special skills, using local materials, maintaining cultural activities So, a home stay does not damage the environment and even preserve local wisdom and manage home stay using local management.

\section{Home Stay Regulation on Village Yard Land}

As explained above, the law of economic development is an aspect of regulating economic enterprises in the sense of increasing overall economic life. According to this economic law, every citizen has the opportunity to develop his economic efforts including the construction of tourism facilities in the form of home stay, but from the perspective of Balinese Customary Law (Awig-awig and Perarem), especially in the research area, home stay arrangements established on the Village Yard Land does not yet exist in the tourist area of Ubud. So based on the awig-awig (customary rules) the Customary Village has not set about building a home stay on the Village Yard Land. To reduce the proliferation of tourism problems in Ubud, traditional villages or customary village and local governments as holders of authority and legitimacy along with stakeholders, interacting directly at the implementation level, should begin issuing regulations and sustainable tourism development concepts in order to maintain the consistency and continuity of the Ubud tourism area.

There is also no Custom Village regulating the operational permit for home stay ownership, because many traditional village residents use their house as a home stay. If the home stay development is not regulated by the Custom Village as the authority of using the village land, then the villagers will also be more free to use custom land including changing the structure of the Balinese custom housing. Chairperson of Ubud Home Stay Association (UHS) I.B. Wiryawan said: "At present there are already more than 200 home stay owners in Ubud and surrounding villages with a total of thousands of rooms. However, to fill the room is very difficult, because of the tight competition". The point is that licensing must be tightened "Do not continue to work in building accommodation" [7].

\section{E. Home Stay Owner Contribution to Customary Village}

In accordance with social economic law, the regulatory aspect of efforts to share the results of economic development equally among all levels of society, so that every Indonesian citizen can enjoy the results of economic development in accordance with his contribution to the economic development effort.

The share results of distribution or contributions from home stay business owners in Ubud tourist areas has not yet been regulated so that the distribution of economic benefits cannot be enjoyed by traditional village residents equally. The Custom Villagers who build a home stay business on the land of village yard should give contributions to Custom Villages as land owners, but so far the home stay owners have only enjoyed the results of the home stay business personally. This happened because there were no regulations issued by the Customary Village to regulate the construction of home stay so the villagers certainly did not feel they had an obligation to pay contributions to the Custom Village. So the operational results of the home stay are only enjoyed by the owner and cannot be enjoyed equally by the Customary Villagers.

\section{CONCLUSION}

Home stay is very potential to preserve the environment as part of sustainable tourism because it has a definite target to preserve natural resources, cultural resources, and human resources. However, the village regulations that regulate home stays in Ubud do not yet exist in the Awig-Awig (Village Regulation) of Customary Villages, so there must be certain rules issued by the Customary Village as the owner of the village Yard Land. With the regulations issued by the Customary Village, the people who build home stay on the Village Yard Land have an obligation to contribute to the Customary Village, and the Customary Village has an obligation to return the funds obtained for the welfare of the community.

\section{REFERENCES}

[1] B. Antariksa, The Policy of Tourism Development. Malang: Intrans Publishing, 2016.

[2] D.M. Swastawa, Status and Function of Bali Custom Land. Denpasar: CV. Kayumas Agung, 1987.

[3] I.W. Surpha, The Existence of Custom Village in Bali. Denpasar: Upada Sastra, 1995.

[4] S. Suryabrata, Research Methodology, Jakarta: CV Rajawali, 1998.

[5] C.A. Van Vursion, Cultural strategic. Yogyakarta: Kanisius, 1995.

[6] Daily, Tribun Bali 27-1-2015, download January, 11, 2018.

[7] News Paper, Bali Travel News, January, 17, 2011. 